University of Denver

Digital Commons @ DU

8-24-2009

\title{
Digitizing the Historical Periodical Collection at the Al-Aqsa Mosque Library in East Jerusalem
}

\author{
Krystyna K. Matusiak \\ University of Denver \\ Qasem Abu Harb \\ Arab Studies Society, East Jerusalem
}

Follow this and additional works at: https://digitalcommons.du.edu/lis_presentation

Part of the Library and Information Science Commons

\section{Recommended Citation}

Matusiak, K.K. \& \& Abu Harb, Q. (2009). Digitizing the historical periodical collection at the Al-Aqsa Mosque Library in East Jerusalem. Presented at the IFLA World Library and Information Congress, August 24, 2009, Milan, Italy. Available at: http://www.ifla.org/files/hq/papers/ifla75/106-matusiak-en.pdf

This Paper is brought to you for free and open access by the Library and Information Science: Faculty Scholarship at Digital Commons @ DU. It has been accepted for inclusion in Library and Information Science: Faculty Conference Presentations by an authorized administrator of Digital Commons @ DU. For more information, please contact jennifer.cox@du.edu,dig-commons@du.edu. 
Digitizing the Historical Periodical Collection at the Al-Aqsa Mosque Library in East Jerusalem

\section{Publication Statement}

Copyright held by the author or publisher. User is responsible for all copyright compliance 
Date submitted: 05/05/2009

\title{
Digitizing the Historical Periodical Collection at the Al-Aqsa Mosque Library in East Jerusalem
}

M I L A N , I TALY 2009

Krystyna K. Matusiak

Digital Collections Librarian

University of Wisconsin- Milwaukee Libraries

Consultant for the Digitization Project at the Al-

Aqsa Library

Qasem Abu Harb

Records Manager

Arab Studies Society in East Jerusalem

Digitization Project Coordinator at the Al-Aqsa

Library

Meeting:

106. Newspapers

WORLD LIBRARY AND INFORMATION CONGRESS: 75TH IFLA GENERAL CONFERENCE AND COUNCIL

23-27 August 2009, Milan, Italy

http://www.ifla.org/annual-conference/ifla75/index.htm

\begin{abstract}
The Arab Press in Palestine developed at the turn of the twentieth century and proliferated for several decades despite restrictions imposed under the Ottoman Empire and during the British Mandate Period (1917-1948). Hardcopies of the early newspapers and periodicals are rare and access to them at a few Palestinian municipal or private libraries is limited. The Al-Aqsa Mosque Library holds one of the largest collections of Palestinian historical newspapers and periodicals. The collection provides a unique and rich source of information about the history of Palestine in the first half of the twentieth century. Access to the collection is limited and brittle paper copies have been rapidly deteriorating. This paper provides an overview of the digitization project aimed at preserving the historical periodical collection located at the AlAqsa Mosque Library.

\section{Introduction}

Historical newspapers and periodicals represent a rich resource for scholars and researchers, but due to poor quality paper they are also a very fragile source posing many preservation and archiving challenges. Creating microfilm copies of fragile and deteriorating newspapers has been an established preservation method in many developed countries. In the last decade, digitization offered an unprecedented opportunity to expand access to newspaper content and assist preservation by reducing the use of brittle paper copies. Digitization has also become a preservation strategy in countries where microfilming is not easily available.
\end{abstract}


Arab newspapers and periodicals published in Palestine in the first half of the twentieth century provide a unique and valuable source of information about the history of the region and its people. Copies of the historical periodicals and newspapers are, however, extremely rare, since many private Palestinian libraries were destroyed or ceased to exist following the 1948 ArabIsraeli War. The Al-Aqsa Mosque Library holds one of the largest collections of Palestinian newspaper and periodicals. Many of the titles included in the collection are particularly unique as they represent the only copies available in the region. Because of the lack of preservation resources, microfilm copies have never been created. A digitization project at the Al-Aqsa Mosque Library was undertaken primarily as a preservation project with the goal of creating archival quality digital copies of the newspapers and periodicals. In addition, the project aimed at preparing multiple derivative copies to widen access of these rare materials to scholars, students, and the general public and make the collection more visible and accessible. The oneyear project was supported by a grant from the Endangered Archives Programme at the British Library.

\section{Background}

\section{The Al-Aqsa Mosque Library}

The Al-Aqsa Mosque Library is located in the Haram al-Sharif compound in the Old City of Jerusalem. It is considered to be the most important library in Jerusalem and was originally founded to support Al-Aqsa as "a center of intellectual debate and a school for teaching of Islamic sciences” (Nussiebeh, 2007). In the past, the books were dispersed through the Haram al-Sharif compound, primarily in the Al-Aqsa Mosque and the Dome of the Rock building. The official Al-Aqsa Mosque Library was established in 1923 by the Supreme Muslim Legislative Council, under the leadership of the mufti of Palestine Hajj Amin al-Husseini. The books from different buildings in the compound were collected and housed in a single building. The library was named dar kuttub al-masjed Al-Aqsa (literally, house of the books of the Aqsa Mosque). As Natsheh (2001) notes, the name has a remarkable implication. It was hoped that Al-Aqsa Mosque Library as a "house of books" would become as important to Islamic studies as the National Library at Cairo and the National Library at Damascus 'al-Zahiryya'. However, due to the political circumstances under the British Mandate and after the 1948 Arab-Israeli War, this promise was never fully realized (Natsheh, 2001).

The location of the library has shifted within the Haram al-Sharif compound several times. In 2000 the library was moved to its current location between the Al-Aqsa Mosque on the east side and the Islamic Museum on the west. The building in which the library is now housed is the historic building known as the "Jami' al-Nisa”, or "Women’s Mosque”, dating back to the Crusader period in the 12th century. The library is open to the public between 9am and 1pm, from Saturday to Wednesday, but access is often hindered by extensive security checks at the al Haram's gates. Natsheh (2001) points out that in fact many Palestinian students from West Bank are unable to access the library due to security restrictions.

The Al-Aqsa Mosque Library is a reference library intended to serve the needs of researchers and students from Jerusalem and other Palestinian cities. The library contains monographs, periodicals, and manuscripts. There are about 1,000 manuscripts as well as 644 Qura'ns dating from $9^{\text {th }}$ to the $13^{\text {th }}$ century. The oldest, Kufic text is dated from the second century after hijra 
(Jacobsen and Mack, 2007). The monograph collection consists of 10,000 books including 2000 rare titles. The collection includes materials in the following fields: Islamic religion, Arabic language, Arabic literature, and Islamic history. Since 1977, collection development has focused on acquiring books related to Islamic history, archaeology, and art.

The library also contains more than 70 titles of Arabic language newspapers and journals, published in Palestine and other Arab countries as well as a selection of periodicals published by the Arab communities in Europe and North and South America. Many of the publications were purchased for the library holdings, while others were acquired from private libraries and through donations from both private and public sources. The newspaper and periodical collection faces the risk of rapid deterioration due to poor quality paper, environmental factors, and the lack of a preservation program. The digitization project was initiated to create multiple digital copies of the endangered material.

\section{The Development of the Arab Press in Palestine}

Arab newspapers and periodicals in Palestine developed later than the press in neighboring Arab countries like Lebanon, Egypt, and Syria that had already established a vibrant press in the second half of the nineteenth century (Ayalon, 1995; Mellor, 2005). The Palestinian press developed at the turn of the twentieth century when Palestinian Arabs, often trained at the Christian publishing houses, began to establish their own printing presses. Prior to that, the Palestinian reading public had to depend on Arabic periodicals published in neighboring countries (Musallam, 2005). Al-Jinan of 1874, held at the Al-Aqsa Mosque Library and included in the digitization project, is an example of an early Arabic language magazine, published in Beirut, Lebanon (Figure 1). Musallam (2005) points out that Christian Arabs educated at Christian schools in Palestine, contributed significantly to the intellectual and educational revival of the Arabs of Palestine and were involved in the publication of the majority of Arab papers and periodicals that appeared between 1908 and 1914.

Political changes that occurred in the Ottoman Empire, following the Young Turks rebellion in 1908 and resulting in the restoration of the 1876 Constitution and the abolishment of censorship, had a positive impact on the development of the Arabic language press. Additionally, in Palestine, as Ayalon (1995) notes, "Zionist settlement constituted an additional incentive for the emergence of Arabic publications, many of them, although not all, opposed to the new Jewish presence” (p.66). Three major Arabic language papers were established during this period in Palestine and all of them were published by Christian Arabs: al-Quds began to appear in 1908 in Jerusalem; al-Karmil established by Najib Nassar in Haifa in 1908, and Filastine (Figure 2) that became a leading Palestinian paper, was founded by 'Isa al-Isa in 1911 in Jaffa. Al-Karmil and Filastine played a leading role in rising Arab nationalism and opposition to Jewish immigration (Ayalon, 1995; Musallam, 2005).

In addition to Filastine, other papers established in the post-1908 period have been selected for the digitization project, including Al Hasna, Tazwir Afkar, and Al-Muqtabas. Many leading Palestinian intellectuals, such as Is‘af al-Nashashibi, Khalil Baydas, Khalil Sakakini, Ruhi alKhalidi, 'Isa al-'Isa, Hanna 'Abd Allah 'Isa, Najib Nassar, 'Adil Jabr, Musa al-Naghribi contributed to the papers (Musallam, 2005). Many of them had careers outside of journalism and were active in education, politics, and religion, which according to Rugh (1979), was quite 
characteristic for the Arabic language press of that time. In addition to the news, the papers also had significant literary sections, thanks to contributions of prominent writers like Khalil Sakakini. With the outbreak of the World War I in 1914 and the entrance of the Ottoman Empire into the war, political and publishing activities of the Palestinian Arabs were suppressed and several publishers, such as 'Isa al-Isa and Najib Nassar, were exiled or imprisoned.

With the defeat of the Ottoman Empire and the establishment of British control over Palestine, press activities re-emerged in 1919. Two of the leading pre-war papers, al-Karmal and Filastine, re-opened after their owners, Najib Nassar and 'Isa al-'Isa returned from exile. The press landscape in Palestine during the British Mandate (1917-1948), however, was more diverse than in the pre-war period. While Christian Arabs established most of the early periodicals, Muslim Arabs also participated in publication of new papers in the 1920s and 1930s, reflecting rising Arab national consciousness and different political factions. Mirat AlSharq - "Mirror of the East" (Figure 3) was established by a Christian, Bulus Shihada, in 1919. A major organ of the Supreme Muslim Council, Al-Jami'ah Al-Arabiah - "Arab Union” (Figure 4), began to appear in 1927. In the 1920s, approximately 20 new papers were established in Jerusalem, but the early 1930s, Jaffa became the center of Palestinian Arab journalism. In addition to Filastine, Al-Sirat Al-Mustaqim - "The True Path”, (Figure 5) a Muslim paper was launched in Jaffa in 1925. Sawt al-Haqq, another Islamic organ was also published in Jaffa. Most of the Arabic language papers were opposed to the Zionist movement and were critical of British policies in Palestine, but also varied in their political positions. Ayalon (1995) notes, "it was a variegated press scene, mirroring a multipolar polity” (p. 97).

During the 1920s, the growing Arabic language papers in Palestine enjoyed a relative freedom of press. The British adopted the old Ottoman Press Law, which required licensing and the submission of translations of press extracts to the government authorities. Nevertheless, direct interference of the British authorities was rare. Scholars tend to agree that despite those restrictions "the period until 1929 proved to be the most liberal era in the thirty-one years of British rule in Palestine” (Musallam, 2008). Ayalon (1995) points out, "Palestinian journalists enjoyed more freedom of expression during the 1920s than their colleagues in some of the other states in the region" (p. 98).

British liberal policy towards the Arabic language press, however, changed in the following decade. The Buraq riots of 1929 represent a turning point in the modern Palestinian history, followed by violent confrontations between Arabs and Zionists, and Arabs and the British that culminated in the Arab rebellion of 1936-1939. The Shaw Commission, investigating the riots of 1929 pointed out the role of the press in inciting the public and recommended the reevaluation of the press law. The British government in Palestine issued a new Publication Law in January of 1933, giving the authorities sweeping powers to deny or withdraw publication permits, suspend or close down papers, and punish journalists (Ayalon, 1995). The law was amended several times, and in 1933 and 1939, emergency regulations were introduced, restricting freedom of press even further. With the outbreak of the Arab rebellion in 1936, emergency regulations required that all papers submit galley proofs for censorship (Musallam, 2008). 
Following the 1929 crisis, the Arabic language press adopted an increasingly militant position and played an important role in the growing Arab nationalist movement. Several papers became dailies with the Jaffa-based Filastine and Al-Jami'ah Al-Arabiah in Jerusalem. The most important papers established in the 1930s were published in Jaffa, including Al-Difa"Defense” an organ of the Istiqlal Party, and Al-Jami'a Al-Islamiah -“Islamic Union” (Figure 6), that appeared from 1932 to 1937. Al-Liwa' - "The Flag” (Figure 7) representing the dominant party, the Arab Party, was established in Jerusalem in 1933. The British authorities responded with harsher measures against the increasingly nationalistic and political tone of the Arabic language newspapers. As Najjar (1975) documents many major newspapers, such as Falastin, Al-Difa, Al-Liwa, Al-Sirat Al-Mustaqim, and others, were confiscated for extended periods of time in 1937 and 1938. With the outbreak of World War II and introduction of new emergency laws, the British ordered the closure of almost all papers. Only Filastin and al-Difa' were able to survive by adopting a moderate nationalist tone and publishing closely censored news.

\section{Project Goals}

The collection at the Al-Aqsa Mosque Library includes major Palestinian newspapers and periodicals from the pre-war and the British Mandate periods, such as Filastine, Mirat AlSharq, Al-Jami'ah Al-Arabiah, Al-Jami'a Al-Islamiah, Al-Difa, and others. The collection is housed at the Al-Aqsa Mosque Library along with other library materials posing many preservation and access challenges. Walravens (2008) identifies preservation and access as major issues in managing newspaper collections, noting that "the challenge is greater than with other library materials” (p. 1). The digitization project undertaken at the Al-Aqsa Mosque Library in 2008 aimed at addressing preservation of this unique historical collection, but also at expanding access to a wider community of scholars and students.

\section{Preservation}

The primary goal of the project was to create digital archival copies of rare papers in order to safeguard the collection housed at Al-Aqsa Mosque Library from the risk of physical deterioration and destruction. The copies at the Al-Aqsa Mosque Library have been deteriorating rapidly because of their use, poor environmental conditions, the lack of a preservation program, and the shortage of staff trained in conservation and preservation methods (Figure 8 and 9). The Al-Aqsa Mosque Library has only print copies of the periodicals, since microfilming as a preservation method was not considered in the past. The print copies of newspapers and periodicals served as a source for creating a digitized version of the collection. Digitization was selected as a conversion method and a way of creating digital copies to reduce the handling of the fragile print materials.

\section{Access}

The secondary goal of the project was to create multiple derivative digital copies to make the collection more accessible and visible and address the issue of limited access to the Al-Aqsa Library. In addition to expanding access to the collection, the project also aimed at enhancing the indexing and searchability of the newspapers by creating searchable text through Optical Character Recognition (OCR) technology and providing full-text keyword search. Original newspapers in the library are organized by title and date, but have no indexes that would enable subject access. Interestingly, several of the early magazines, such as Al-Muqtabas (1906-1912) 
were published in bound volumes with a table of contents that provided access to all issues in a given year. The digitized version of Al-Muqtabas, in addition to providing searchable text, maintains this original arrangement of the published volumes.

\section{The Selection of Titles}

The periodical collection at the Al-Aqsa Mosque Library consists of historical newspapers, journals, and magazines in multiple formats. 24 titles, including 13 newspapers and 11 journals and magazines, were selected for the digitization project. Most of the periodicals were published in Palestine during the British Mandate Period (1917-1948), but among the selected titles there is also a publication from the time of the Ottoman Empire, Al-Jinan (1874), and a few publications from the pre-war period, such as Al-Mahaba (1901), Al Hasna (1909-1912), Tazwir Afkar (1909), and Al-Muqtabas (1908-1916). Table 1. includes the list of the selected titles and their publication dates.

\begin{tabular}{|c|c|c|c|}
\hline Title in English & Title in Arabic & Periodical Type & Coverage \\
\hline 1 Majalet Rawdat al-Ma’arif & فـراعملا ةضضور ةّلجم & Magazine & 1922-1923; 1932; 1934 \\
\hline 2 Al-Kuliyya al-Arabia & ة تيبرعلا ةيلكلا & Magazine & 1927-1938 \\
\hline 3 Al-Houkouk & قوق حلا & Magazine & $1923-1928$ \\
\hline 4 Al-Moktubas (Al-Muqtabas) & سبتقمل| & Magazine & $1907-1912$ \\
\hline 5Al-Arab & 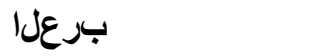 & Magazine & $1933-1934$ \\
\hline 6 Al-Jinan & 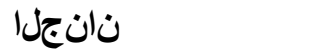 & Magazine & 1874 \\
\hline 7 Al-Mahaba & قبعملا & Magazine & 1901 \\
\hline $8 \mathrm{Al}-H a s n a$ & عانسحل & Magazine & $1909-1912$ \\
\hline 9 Al-Zahrah & تزمزل & Magazine & $1922-1926$ \\
\hline 10 Rawdat al-Maaref & فراعملا ثضور & Magazine & 1326-1327 AH \\
\hline $11 \mathrm{Al}-\mathrm{Fajr}$ & رجفل & Magazine & 1935 \\
\hline 12 Al-Jami’a Al-Islamiah & قيمالسالا ةعماجل & Newspaper & 1932-1938 \\
\hline 13 Al-Jami'ah Al-Arabiah & قيبرعلا ةعماجلا & Newspaper & $1932-1938$ \\
\hline 14 Al-Sirat Al-Mustaqim & ميقتسمل| طارصلا & Newspaper & $1928-1936$ \\
\hline 15 Sawt al-sha’b & بعل بل توص ت & Newspaper & 1928-1930; 1934 \\
\hline 16 Al-Awqat Al-‘Arabiah & ةيبرعلا تاقوالا & Newspaper & 1935 \\
\hline 17 Al-Liwa & عاول عال & Newspaper & $1935-1937$ \\
\hline 18Tazwir Afkar & راكفا ريوصت & Newspaper & 1909 \\
\hline 19 Al-Muqtabas & سبتقملا & Newspaper & 1908-1912; 1915-1916 \\
\hline 20 Al-Qabas & سبقل & Newspaper & 1913-1914 \\
\hline 21 Al-Difa’ & عافدلا & Newspaper & 1934-1951 \\
\hline 22 Falastin (Filastin) & نيطسلف & Newspaper & 1923-1937;1947-1951 \\
\hline $23 \mathrm{Al}-I q d a m$ & 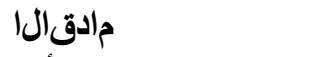 & Newspaper & $1935-1936$ \\
\hline 24 Mirat Al-Shark & قرشل قأرم & Newspaper & $1922-1936$ \\
\hline
\end{tabular}

Table 1. List of Selected Titles

In addition to the major newspapers that played an active role in the Arab nationalist movement during the British Mandate period and often represented different political factions, like Filastin or Al-Jami'a Al-Islamiah, the selection also includes a number of cultural, literary, educational journals, and women's magazines. The digitized collection contains 33 issues of 
Al-Hasna, a women's literary and social magazine, published in Beirut from 1909 and 1912 and distributed to the reading public in Palestine. Al-Zahra was a literary magazine published in Haifa in the 1920s. Al-Fajr, published in Jaffa in the mid-1930s, was a weekly cultural magazine. Its cover often featured a famous foreign actress, which was quite unusual for the Arabic language press of that time (Figure 10). The collection also presents several scholarly journals, such as $\mathrm{Al}-\mathrm{Houkouk}$, a monthly legal and scientific journal, published by Fahmi AlHusseini in Jaffa, or an educational journal Al-Kuliyya al-Arabia, published by Arab College of Jerusalem, with a well-known Palestinian educator, Ahmad al-Khalidi as its chief editor. Most magazines in bound volumes survived in a relatively good condition, but newspapers, printed on poor quality paper, posed many challenges during the digitization process.

\section{Digitization Process}

Several researchers and practitioners point out that newspaper digitization projects are especially challenging because of large format, complex page layout, and poor quality of print (Gilboe, 2005; King, 2005; Klijn, 2008), requiring many libraries to outsource the scanning process. Because of the historical nature of the collection and the location of the Al-Aqsa Mosque Library, outsourcing was not an option and the image capture process had to be performed in-house. The scanning was conducted from the original paper copies since microfilm copies were not available. ATIZ BOOK Drive system with two digital cameras was used to capture images of newspapers. The initial output of the ATIZ BOOK Drive system is in RAW format, which required conversion to TIFF format for archiving purposes. The digitization guidelines were established at the beginning of the project and were based on the general copying guidelines available to the Endangered Archives Programme participants (Endangered Archives Programme, 2009) and technical guidelines of the National Digital Newspaper Program (Library of Congress, 2009).

The digitization guidelines for the project assume a use-neutral approach and are based on digital library standards, best practices, and general principles for building digital collections. The goal of the project was to build a repository of digital master files in the TIFF format for archiving purposes and provide derivative files in the PDF format for current use. The useneutral approach includes the notion of digital master files and derivatives.

\section{Archival Master Files}

Digital master files were created as a direct result of the scanning process. General recommendations for digital master files include:

- Scan at the highest quality affordable; minimum 300 dpi resolution

- Use lossless compression

- Save in a non-proprietary format, such as TIFF

- Use a consistent file naming convention

The process of creating digital masters usually results in large file size. Their primary function is to serve as a long-term archival file and a source for derivative files. The digital master files created as a result of this digitization project constitute the digital periodical repository. One set of digital master files is stored at the Al-Aqsa Library. The second was deposited at the British Library, according to the Endangered Archives Programme requirements. The digital masters can serve not only as preservation copies, but also as a source for creating multiple derivative copies in the future. 
A consistent file naming convention was established in order to manage the project effectively. File names for digital masters and PDF derivatives were established prior to the scanning process. Each title was assigned a unique three letter Scan ID. For this digitization project the following file naming convention has been established:

project code_three letter Scan ID + publication date (or issue number)_page numbers (two or three digit page number starting with zero)

EAP119_three letter Scan ID + four digit year + two digit month + two digit day_two digit page number starting with zero, for example: EAP119_arb19330414_01 for the first page of the issue of Al-Arab published on April 14, 1933

\section{Derivative Files and the OCR Process}

Derivative files were created from digital master files for access. For the purpose of this project derivative files were created in the PDF format. Readiris Pro 11 Middle East edition software, capable of recognizing Arabic language characters was used to perform Optical Character Recognition (OCR), to convert images into searchable files, and to create derivative files in the PDF format. The OCR process was fully automated without any manual editing due to a large volume of files. Quality control of the processed text files, however, demonstrated that the accuracy of the OCR performed with Readiris Pro 11 is relatively low. OCR accuracy for the Arabic language can be generally lower than for Latin characters, but other factors could have contributed to this problem. The output of the OCR is affected by the quality of images, which to a large extent depends on the condition of the original paper. The scanning software and hardware play a role as well as the resolution, but the best scanner or digital camera cannot make up for tears, speckles, poor printing, or bleeding through. In addition, newspapers pose problems for scanning and OCR because of a complex page layout and variety of font types and sizes with titles and headlines typically in much larger letters. Although search and retrieval is not very accurate, PDf files, created as a result of this project, are available for browsing and reading.

The collection is not available online at this point, but the project team is exploring options for presenting the collection on the Web and making it available to a wider audience. The Al-Aqsa Library does not have an appropriate infrastructure for presenting a large online collection, but it is possible that a different non-profit or academic institution will agree to host the collection.

\section{Preservation and Documentation}

Digital images may prove not to be as stable as microfilm for preservation purposes, but nevertheless digitization provides an opportunity to create multiple surrogate copies of endangered materials when other preservation methods are not available. Multiple derivative files of digitized materials also contribute to conservation efforts by providing options for viewing and printing of PDF versions, thereby reducing the handling of deteriorating paper originals. Copies of the publications in the PDF format are also stored at the Al-Aqsa Mosque Library and are available in-house to library users.

In addition to the PDF version, two sets of digital archival copies (in the TIFF format) of the digitized newspapers and periodicals were created. The first set is stored at the Al-Aqsa Mosque Library; the second was deposited at the British Library. Documentation of the 
collection, the project, and the individual publications was also created and deposited at the British Library. The documentation regarding the newspapers and periodicals includes basic descriptive information about each title, such as the title in the Arabic and Latin alphabets, dates and frequency of publication, name of publisher, place of publication, language, and format of the original. The documentation also provides information about the extent and medium of the digitized version as well as an explanation of the system of arrangement of digital files and a reference ID. A number of reference sources were used in the research process to determine the publication titles, dates, and publishing history. Yusuf Q. Khoury's work (Khoury, 1986) was used as a primary source in the research process.

\section{Conclusion}

The project faced a number of challenges due to external factors as well as those directly related to undertaking a large digitization project of historical newspapers. The quality of the original papers, including different text characters, irregular fonts, text density, torn or smudged pages, and a variety in layout posed many challenges during the image capture process. The project team also realized that the digitization process for long-term preservation is very challenging and time-consuming, taking much longer to scan and create digital master files than originally expected. In addition, the project faced a shortage of trained staff and significant budget shortfalls because of the global economic downturn. Despite these challenges, the project team was able to complete the conversion process and prepare an extensive documentation describing the digitized titles. The digitization project provided a unique opportunity to conduct research on the development of the Arabic language press in Palestine and collect information about individual publications and their publishers. The historical newspaper and periodical collection at the Al-Aqsa Mosque Library now exist in multiple formats and is available for research to students and scholars.

\section{References}

Ayalon, Ami. (1995). The Press in the Arab Middle East: A History. New York: Oxford University Press.

Endangered Archives Programme. (2009). Copying Guidelines. Retrieved April 2, 2009 from http://www.bl.uk/about/policies/endangeredarch/pdf/09guidelines_copying.pdf

Gilboe, Lynda James. (2005). “The challenge of digitization: Libraries are finding that newspaper projects are not for the faint of heart.” The Serials Librarian 49 (1/2)

Jacobsen, Peter and Merav Mack. (2007). Survey of Historical Libraries and Archives in Jerusalem: Draft Project Report. Retrieved April 22, 2009 from http://www.writtenheritage.org/EN/progress.html

Khoury, Yusuf Q. (1986). Al-Sihafah al-`Arabiyyah fi Filastin (1876-1948). Beirut: Institute of Palestinian Studies.

King, Edward. (2005). “Digitization of newspapers at the British Library.” The Serials Librarian 49 (1/2).

Klijn, Edwin. (2008). "The current state-of-art in newspaper digitization: A market perspective.”D-Lib Magazine 14(1/2). Retrieved April 14, 2009 from http://www.dlib.org/dlib/january08/klijn/01klijn.html

Library of Congress. (2009). The National Digital Newspaper Program (NDNP): Technical Guidelines for Applicants. Retrieved April 8, 2009 from http://www.loc.gov/ndnp/pdf/NDNP_200911TechNotes.pdf

Mellor, Noha. (2005). The Making of Arab News. Lanham: Rowman \& Littlefield Publishers. 
Musallam, Adnan A. (2005). "Arab press, society and politics at the end of the Ottoman era." Al-Liqa' Journal, 25. Retrieved April 3, 2009 from http://admusallam.bethlehem.edu/publications/EndofTheOttomanEra.htm

Musallam, Adnan A. (2008). "Turbulent times in the life of the Palestinian Arab press: The British era, 1917 -1948.” Al-Liqa' Journal, 31. Retrieved April 3, 2009 from http://admusallam.bethlehem.edu/publications/Turbulent_Times.htm

Najjar, Aida Ali. (1975). The Arabic Press and Nationalism is Palestine, 1920-1948. Unpublished doctoral dissertation, Syracuse University.

Natsheh, Yusuf. (2001). “Al-Aqsa Mosque Library of al-Haram as-Sharif.” Jerusalem Quarterly, 13. Retrieved April 4, 2009, from http://www.jerusalemquarterly.org/details.php?cat=5\&id=134

Nussiebeh, Mazen. (2007). "Islamic libraries in Jerusalem.” Al-Aqsa Journal, 10(1): 21-27. Retrieved April 4, 2009, from http://www.scribd.com/doc/2742257/ALAQSAJOURNAL-ON-PALESTINE-Autumn-2007

Rugh, William A. (1979). The Arab Press: News Media and Political Process in the Arab World. Syracuse, NY: Syracuse University Press.

Walravens, Hartmut. (2008). “Keynote address.” In: The Impact of Digital Technology on Contemporary and Historic Newspapers (pp. 1-8). Proceedings of the International Newspaper Conference, Singapore, 1-3 April, 2008 and the papers form the IFLA World Library and Information Congress, Quebec, Canada, August, 2008. Munchen: K.G. Saur.

\section{Figures}

1. Page from Al-Jinan magazine published in Beirut in1874

2. Title page of Filastine, January 1, 1933

3. Title page of Mirat Al-Sharq, November 11, 1922

4. Title page of Al-Jami'ah Al-Arabiah, January 27, 1927

5. Al-Sirat Al-Mustaqim (The True Path), February 29, 1928

6. Title page of Al-Jami'a Al-Islamiah, November 30, 1932

7. Al-Liwa' February 17, 1936, organ of the Arab Party

8. Damaged title page of Al-Difa, June 4, 1934

9. Page from the Al-Zahra magazine (November 1923), damaged because of the use of adhesive tape

10. Cover page of Al-Fajr magazine, June 1, 1935

\section{Tables}

1. List of Selected Titles for the Digitization Project 


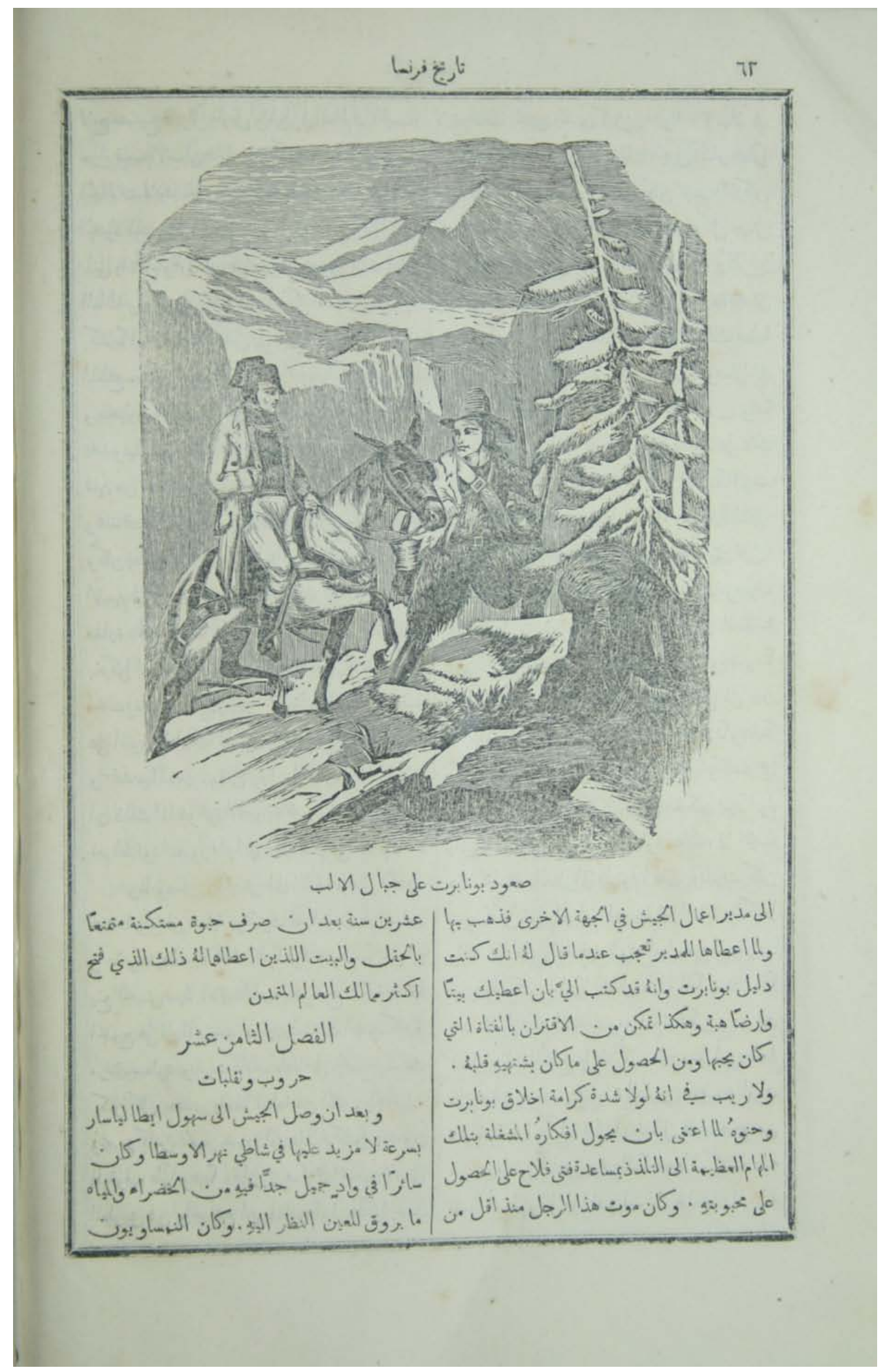

Figure 1 


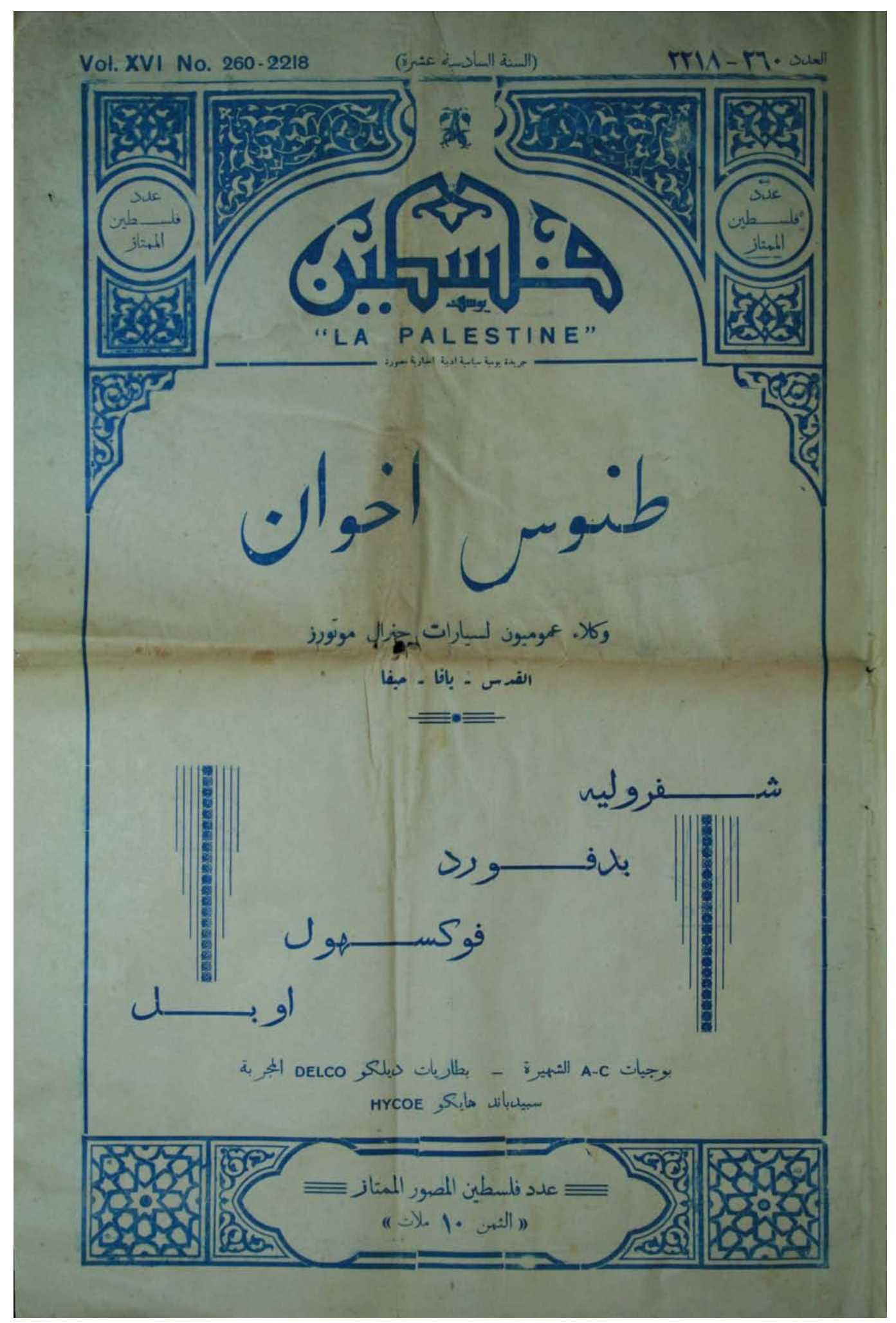

Figure 2 


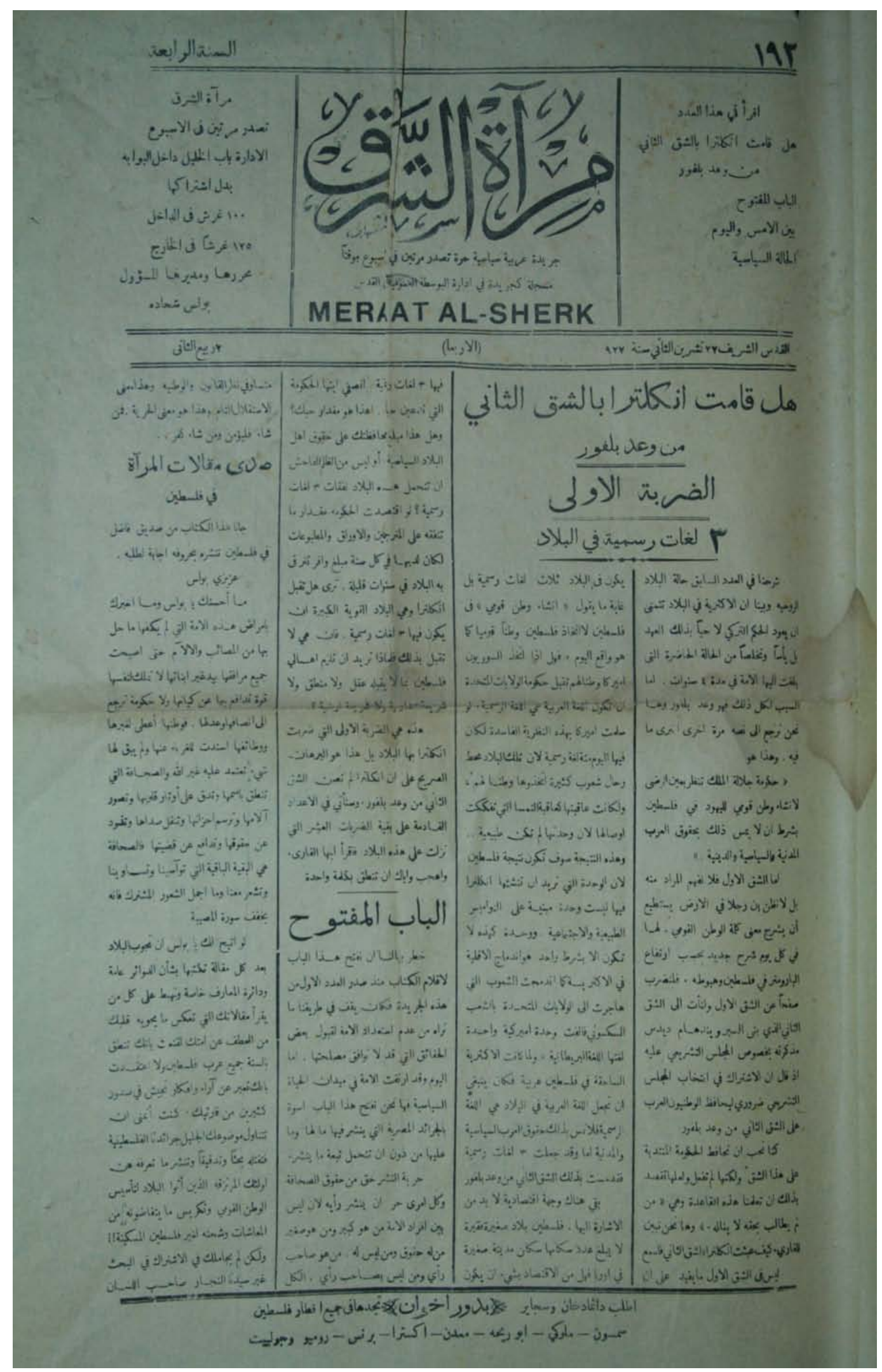

Figure 3 


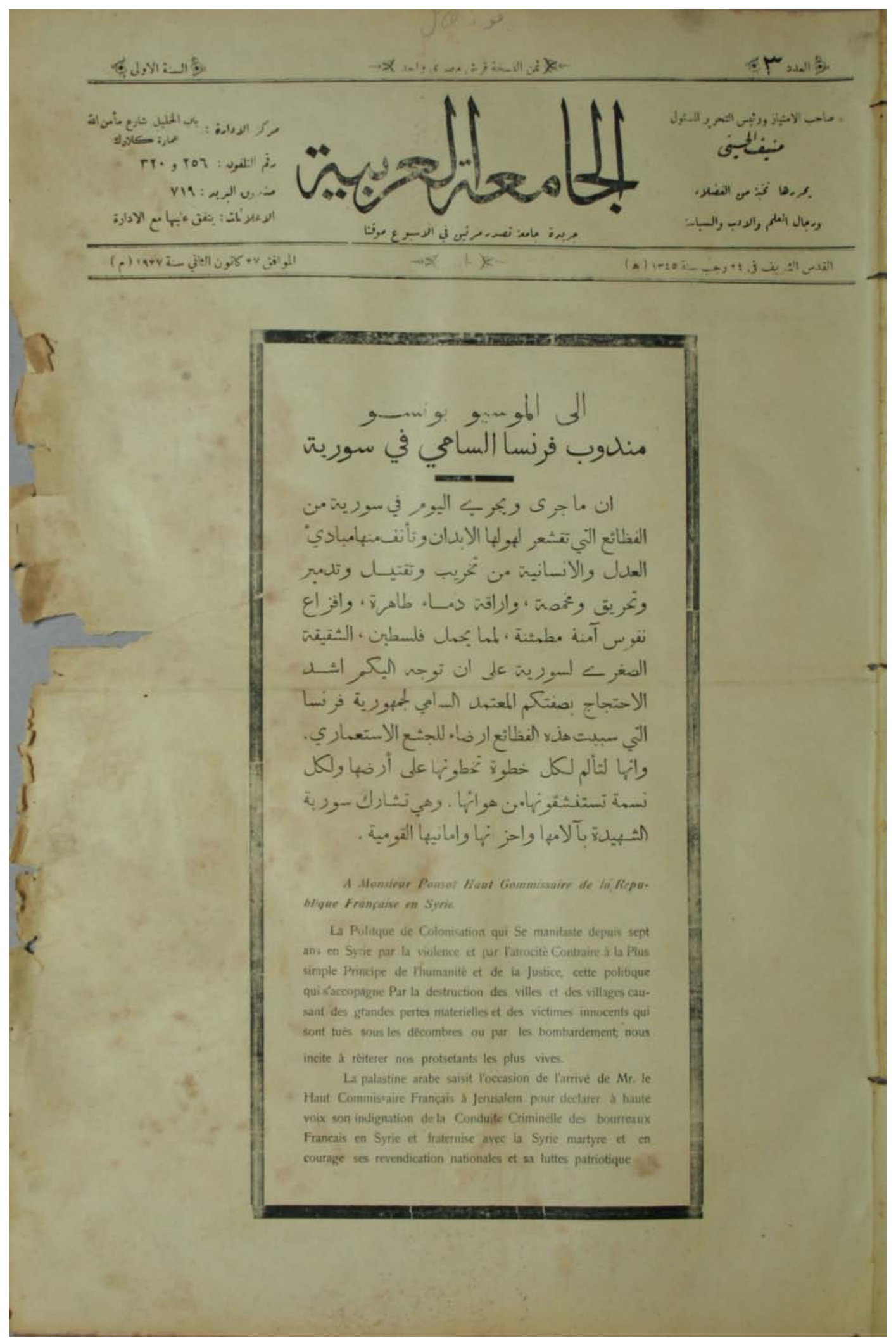

Figure 4 


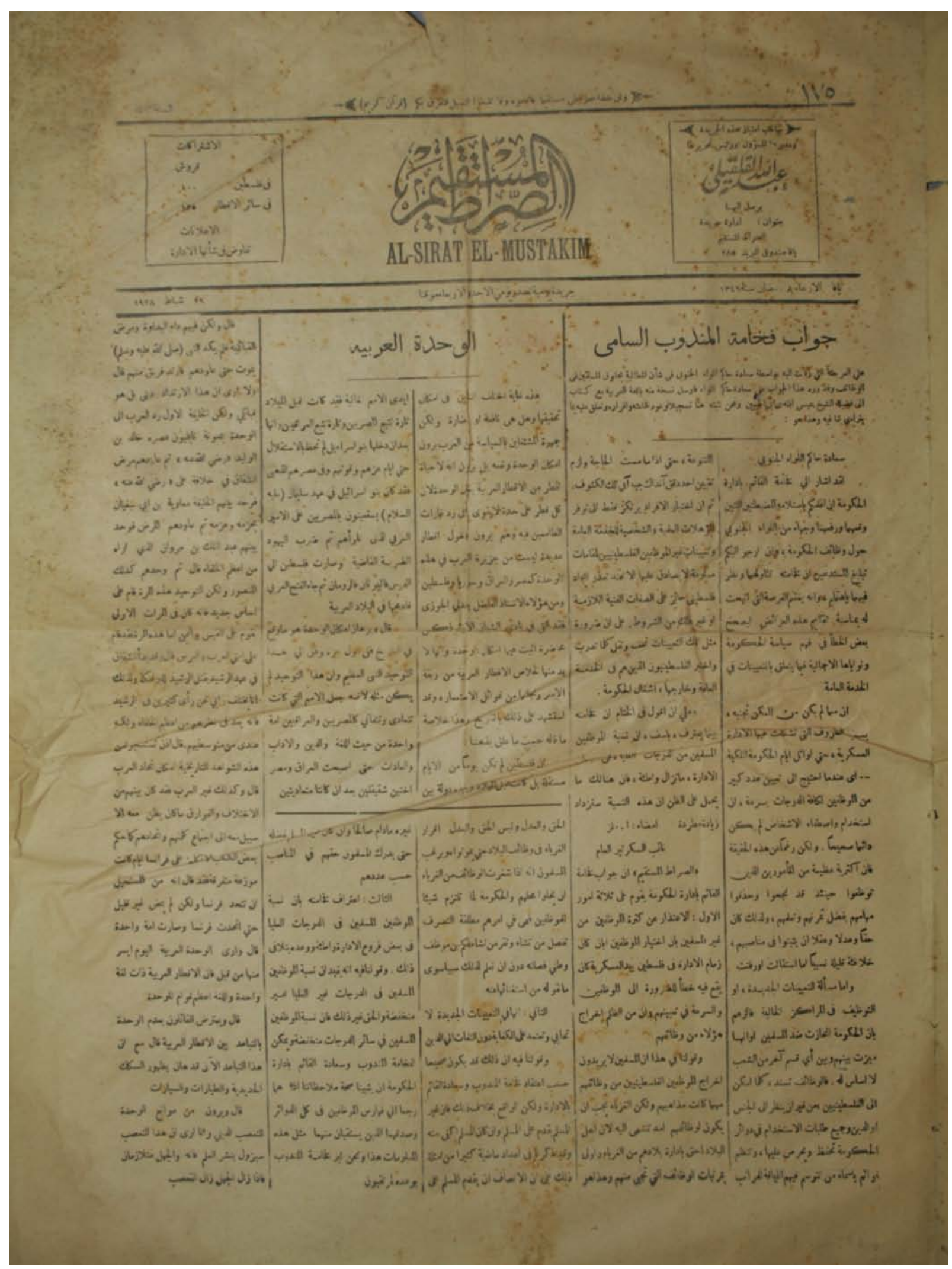

Figure 5 


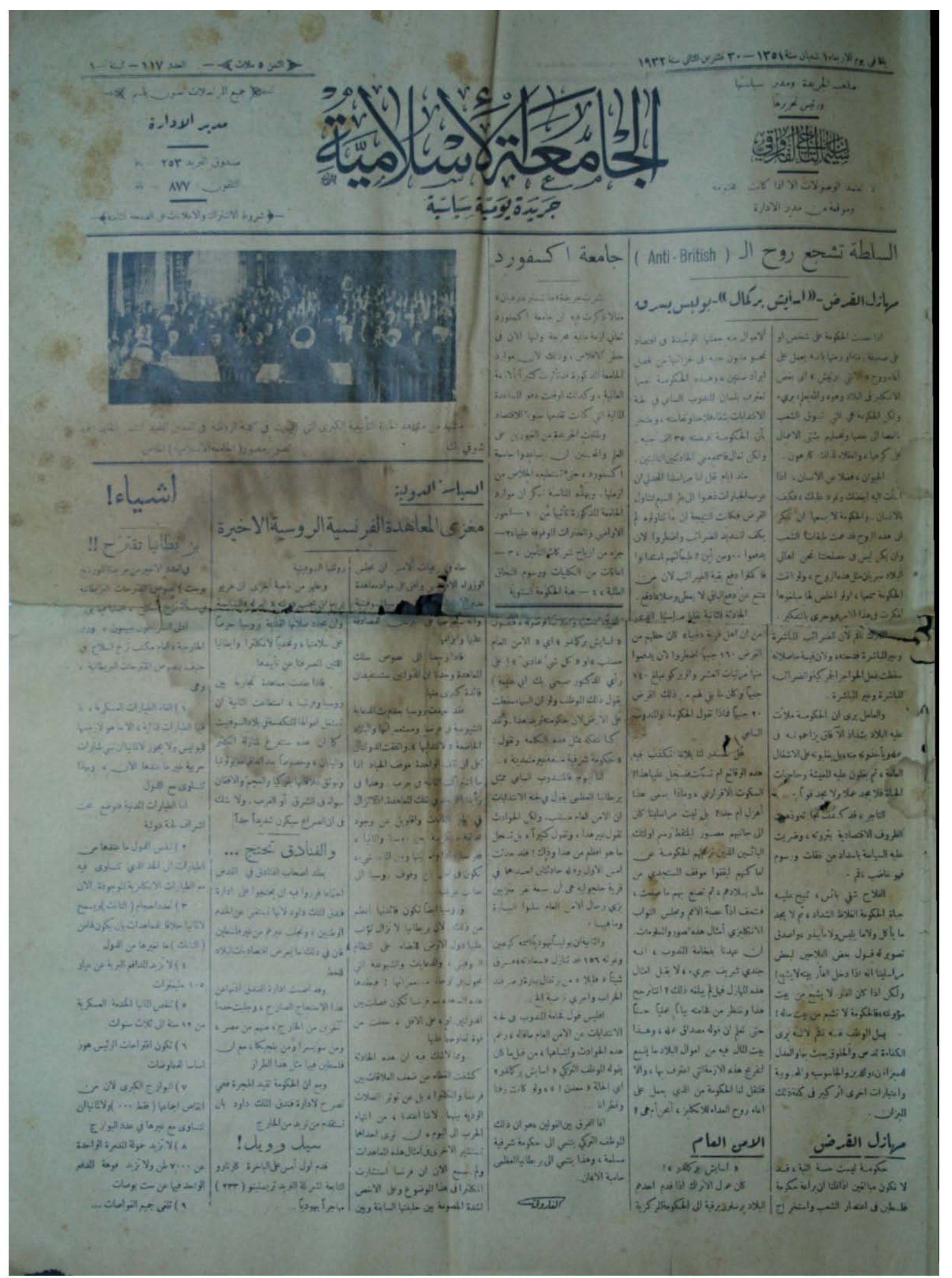

Figure 6 


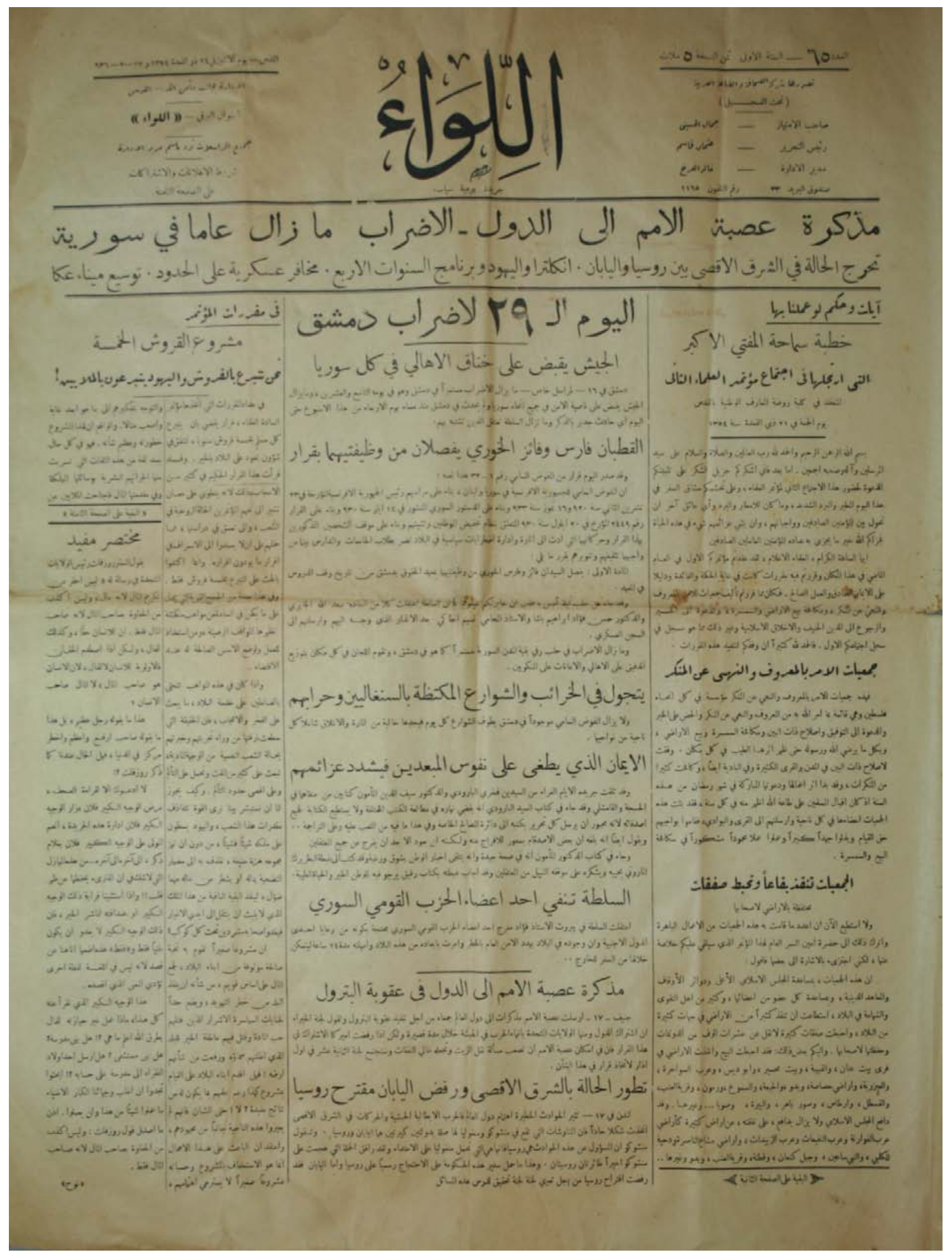

Figure 7 


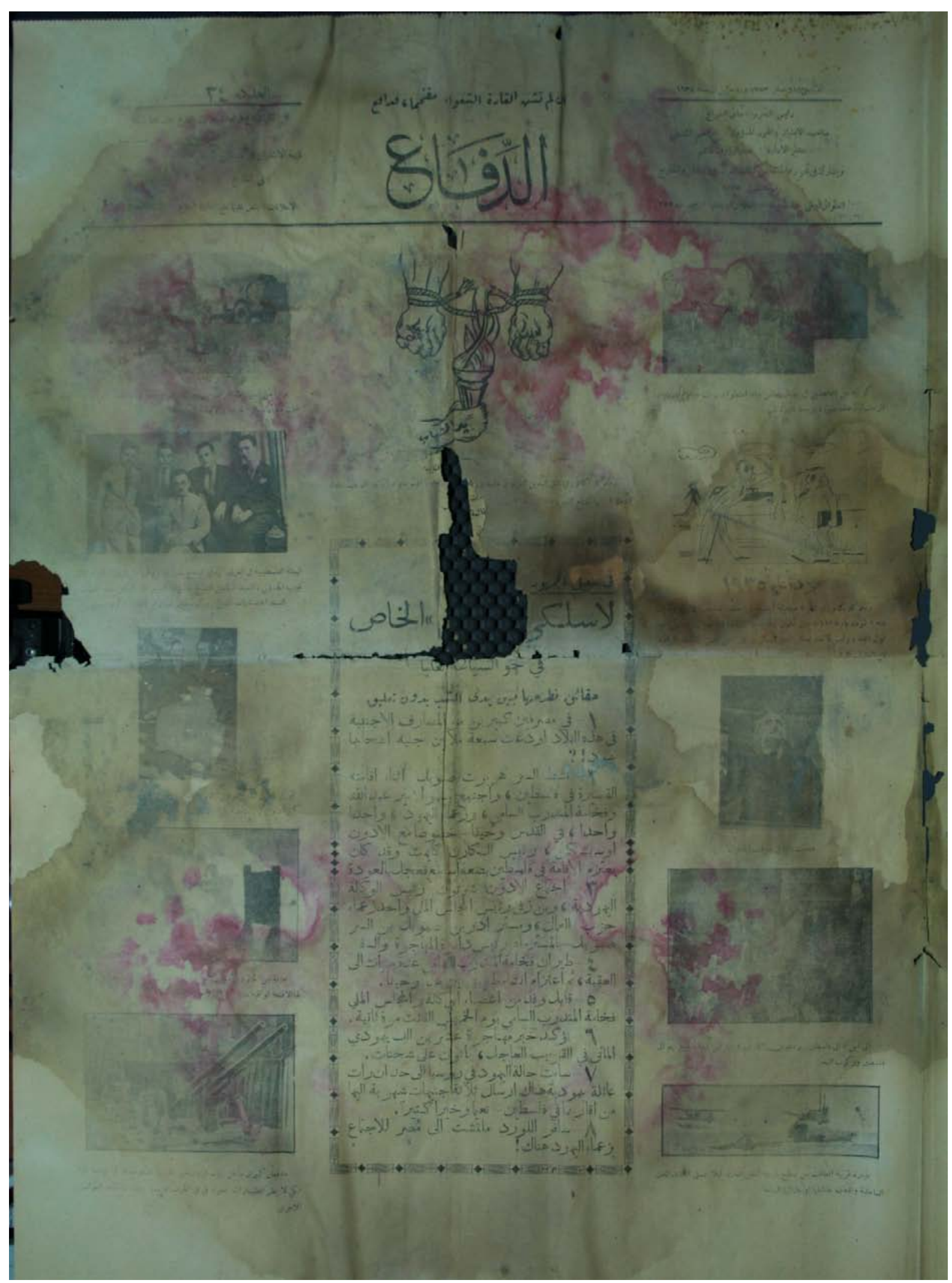

Figure 8 


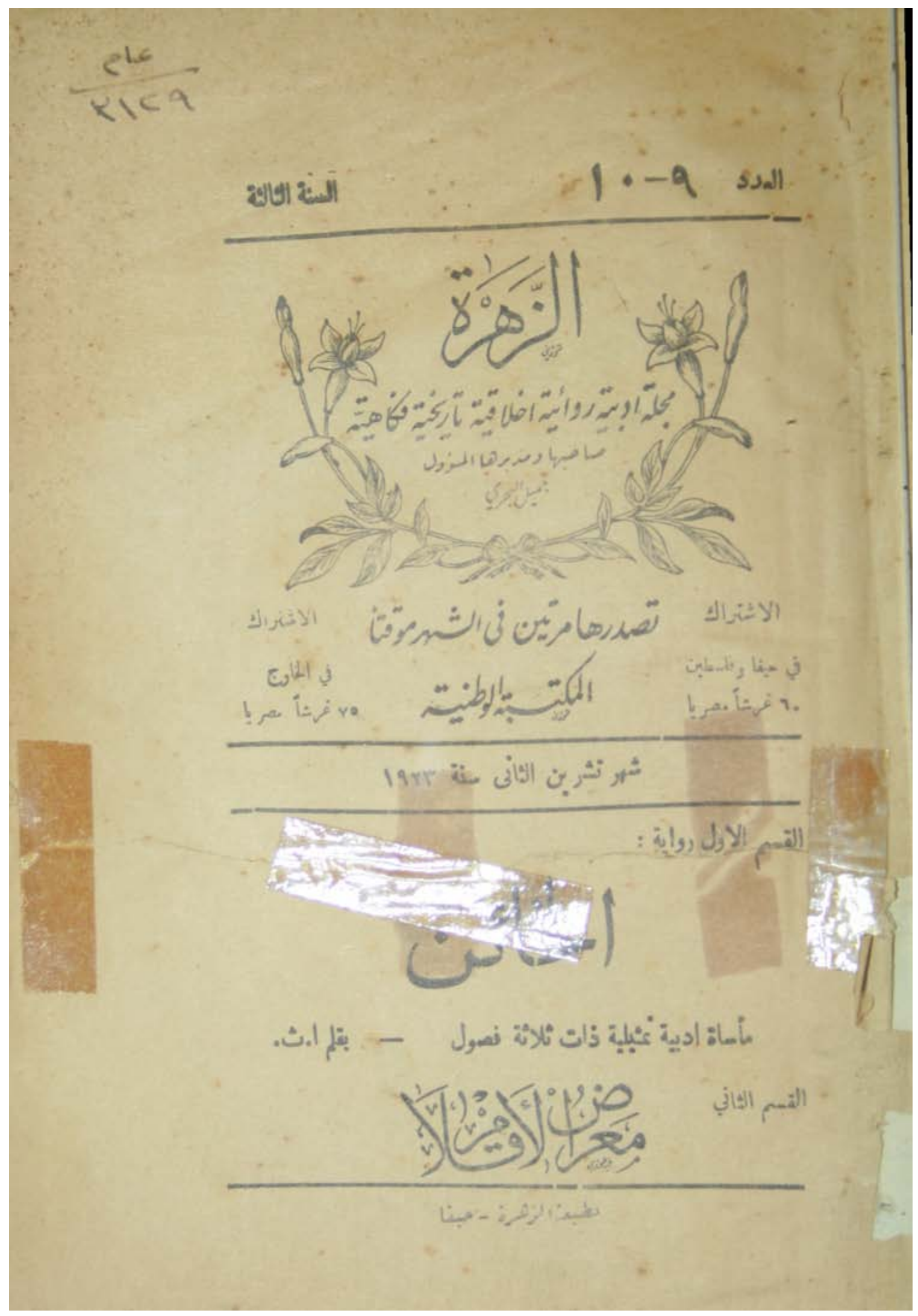

Figure 9 


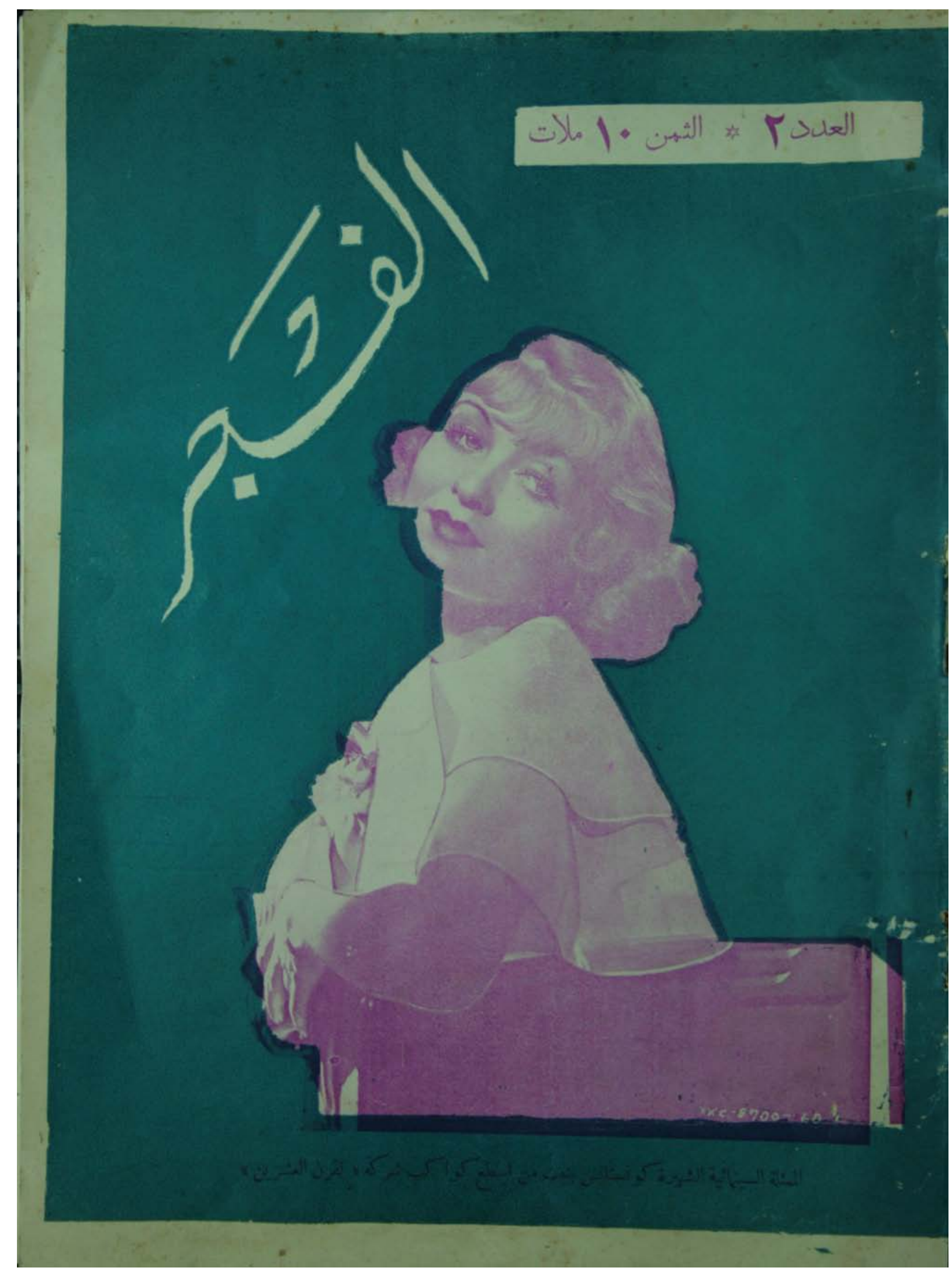

Figure 10 